\title{
Diagenesis makes the impossible come true: intersecting beds in calcareous turbidites
}

\author{
Hildegard Westphal $\cdot$ Jonathan Lavi $\cdot$ Axel Munnecke
}

Received: 20 June 2014 / Accepted: 20 January 2015 / Published online: 8 February 2015

(C) The Author(s) 2015. This article is published with open access at Springerlink.com

\begin{abstract}
Constructing a time-frame of the past is fundamental for any geological interpretation, and the recognition of orbital cycles preserved in the stratigraphic record has revolutionized our understanding of the global timescale, especially for the Cenozoic. In the past decades, astrochronological and cyclostratigraphic approaches based on Milankovitch cycles have become a widely used tool for precisely dating stratigraphic boundaries by calibrating sedimentary units with astronomically tuned timescales. In many cases, strikingly rhythmic limestone-marl alternations are used for such approaches. Astrochronological approaches as a basic principle rely on the fundamental assumption that such rhythmites reflect fluctuating environmental conditions caused by variations in incident solar radiation such as changes in sea level, temperature, or weathering. Nevertheless, in many cases, the crucial question as to whether such rhythmites represent primary cycles or are purely of diagenetic origin has never been positively decided. In those cases, stratigraphic dating with this method is left unreliable. Here, the ability of diagenesis to
\end{abstract}

H. Westphal · J. Lavi

Leibniz Center for Tropical Marine Ecology, Fahrenheitstraße 6, 28357 Bremen, Germany

H. Westphal $(\bowtie) \cdot$ J. Lavi

Department of Geosciences, University of Bremen, Bremen, Germany

e-mail: hildegard.westphal@zmt-bremen.de

Present Address:

J. Lavi

School of Earth, Atmospheric and Environmental Science, University of Manchester, Manchester, UK

A. Munnecke

GeoZentrum Nordbayern, FG Paläoumwelt, Loewenichstr. 28,

91054 Erlangen, Germany produce rhythmic bedding lacking any relation to primary sedimentary signals is demonstrated. The Miocene succession discussed here shows two cemented sets of beds with different inclinations, one parallel to the sedimentary layering, the other, coeval, but in an oblique direction. These two sets merge and do not show distinct boundaries, thus indicating synchronous cementation. It is interpreted that minor early synsedimentary tectonic stress introduced an oblique anisotropy. During early differential diagenesis, this dual anisotropy influenced the geometry of the cemented layers, giving the impression of intersecting layers.

Keywords Astrochronology $\cdot$ Limestone-marl alternations $\cdot$ Diagenesis $\cdot$ Stratigraphy $\cdot$ Miocene $\cdot$ Turbidites

\section{Introduction}

Limestone-marl alternations have a striking appearance because of the lateral continuity of beds and interbeds, and the repetitive bimodal intercalation of the two distinct lithologies. While they traditionally have been interpreted as archives of bimodally fluctuating environmental conditions (Seibold 1952; Einsele 1982; Elrick and Hinnov 2007), doubt has long been shed regarding their environmental origin, and the effects of diagenesis have been discussed controversially (Sujkowski 1958; Hallam 1964, 1986; Ricken 1986; Möller and Kvingan 1988; Munnecke and Samtleben 1996; Boulila et al. 2010, 2011; Mattioli et al. 2011). The main reason for controversy is that the two intercalated lithologies in such rhythmites have undergone distinctly different postdepositional processes (Ricken 1986), so-called differential diagenesis (Reinhardt et al. 2000; Westphal et al. 2000). Specifically, limestone beds have been cemented during early 
diagenesis by import of calcium carbonate cement, and they are preserved largely uncompacted (Munnecke and Samtleben 1996). The interbeds, in contrast, at the same time have been subject to dissolution of calcium carbonate and were being compacted by increasing sediment loading (Ricken 1986; Munnecke and Samtleben 1996; Westphal et al. 2000). Differential diagenesis is initiated by changes in pore-water chemistry caused by microbially mediated decay of organic matter (Raiswell 1987, 1988; Walter and Burton 1990; Canfield and Raiswell 1991; Walter et al. 1993) which takes place in defined depth intervals, causing the resulting diagenetic patterns to develop parallel to the sea floor, and thereby in most cases also parallel to the sedimentary layers. According to Munnecke and Samtleben (1996) and Westphal et al. (2000, 2008a), the carbonate cement in calcareous rhythmites such as limestone-marl alternations that fills the pore space of the (later) limestones derives from selective dissolution of aragonite in the non-cemented layers (marls). This process takes place close to, and thus parallel to, the seafloor during early marine shallow-burial diagenesis.

The parallel orientation of sedimentary and diagenetic patterns generally makes the distinction between the sedimentary and diagenetic bedding difficult or even impossible. At the same time, differential diagenesis alters rock parameters such as carbonate content, color, and magnetic susceptibility differently in the cemented and uncemented lithologies. This is most apparent for carbonate contents that diagenetically increase in the cemented beds whereas at the same time they decrease due to dissolution in the interlayers. This is also the case for other parameters including porosity, permeability, palynomorph concentration, and stable isotope composition (Ricken 1986; Munnecke et al. 2001). These parameters can then no longer be used as the basis for cyclostratigraphic interpretation on the couplet scale (Westphal et al. 2008a, 2008b, 2010). In order to determine whether calcareous rhythmites reflect primary sedimentary differences, rock parameters that are inert to differential diagenesis need to be studied, such as palynomorph associations (as opposed to simple concentrations), and the ratios of diagenetically stable elements such as Ti/ $\mathrm{Al}$ (Westphal et al. 2000, 2008a, 2008b, 2010).

An example is presented here that shows a distinct angle between two sets of coeval diagenetic bedding, one following sedimentary bedding, the other oriented oblique to sedimentary bedding. This example verifies and demonstrates in striking clarity that diagenesis can create bedding independent of primary depositional layers.

\section{Materials and methods}

The Miocene (Burdigalian to Lower Langhian) Banyalbufar Turbiditic Formation consists of $350 \mathrm{~m}$ of sediments filling an actively subsiding trough (Pomar et al. 1990). These sediments have been interpreted as calcareous turbidites deposited during a time of rapid deepening of the Valencia Trough related to Alpine tectonics (Rodríguez-Perea 1986-1987). The Valencia Trough is a NE-SW-oriented extensional

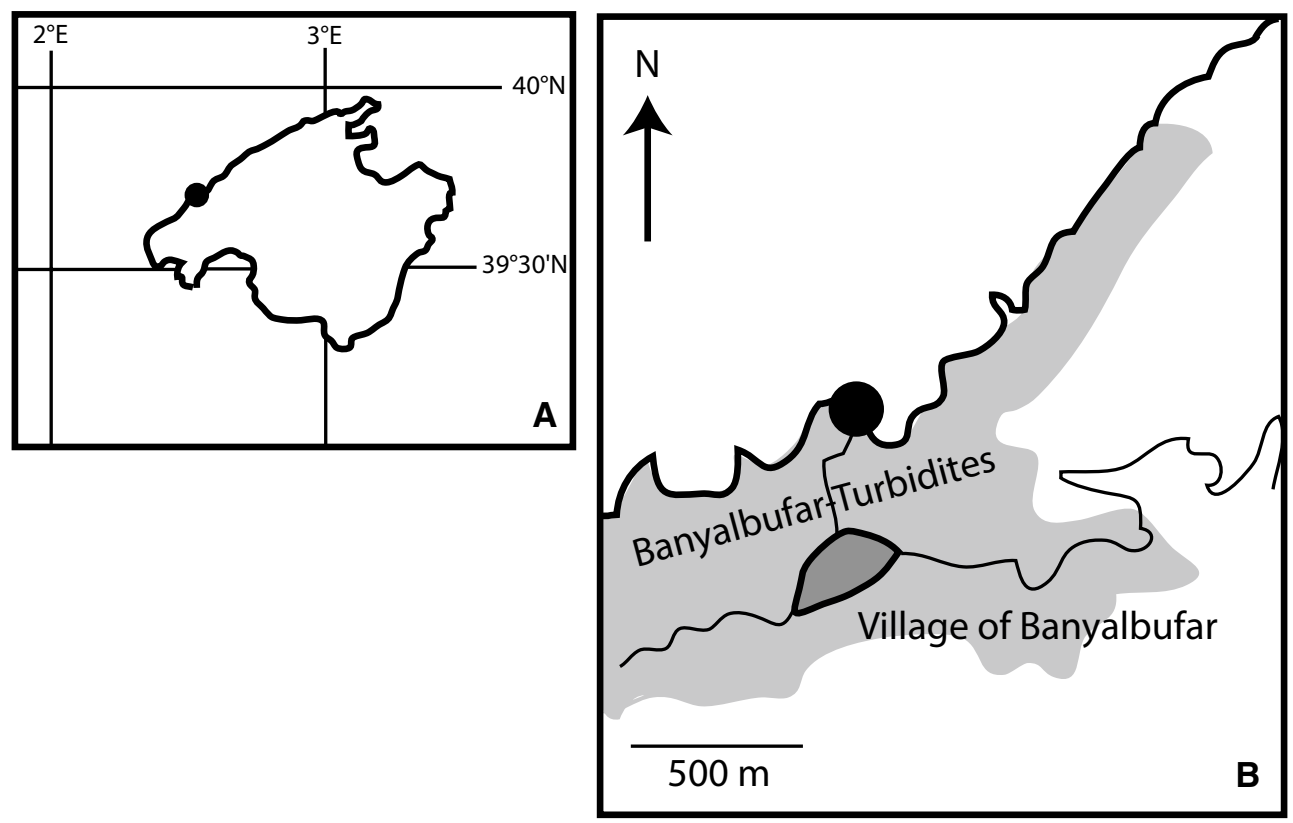

Fig. 1 a Location of the village of Banyalbufar (black dot); Island of Mallorca, b close-up; outcropping Banyalbufar Turbidites are shaded in grey; outcrop studied is marked with a black dot 

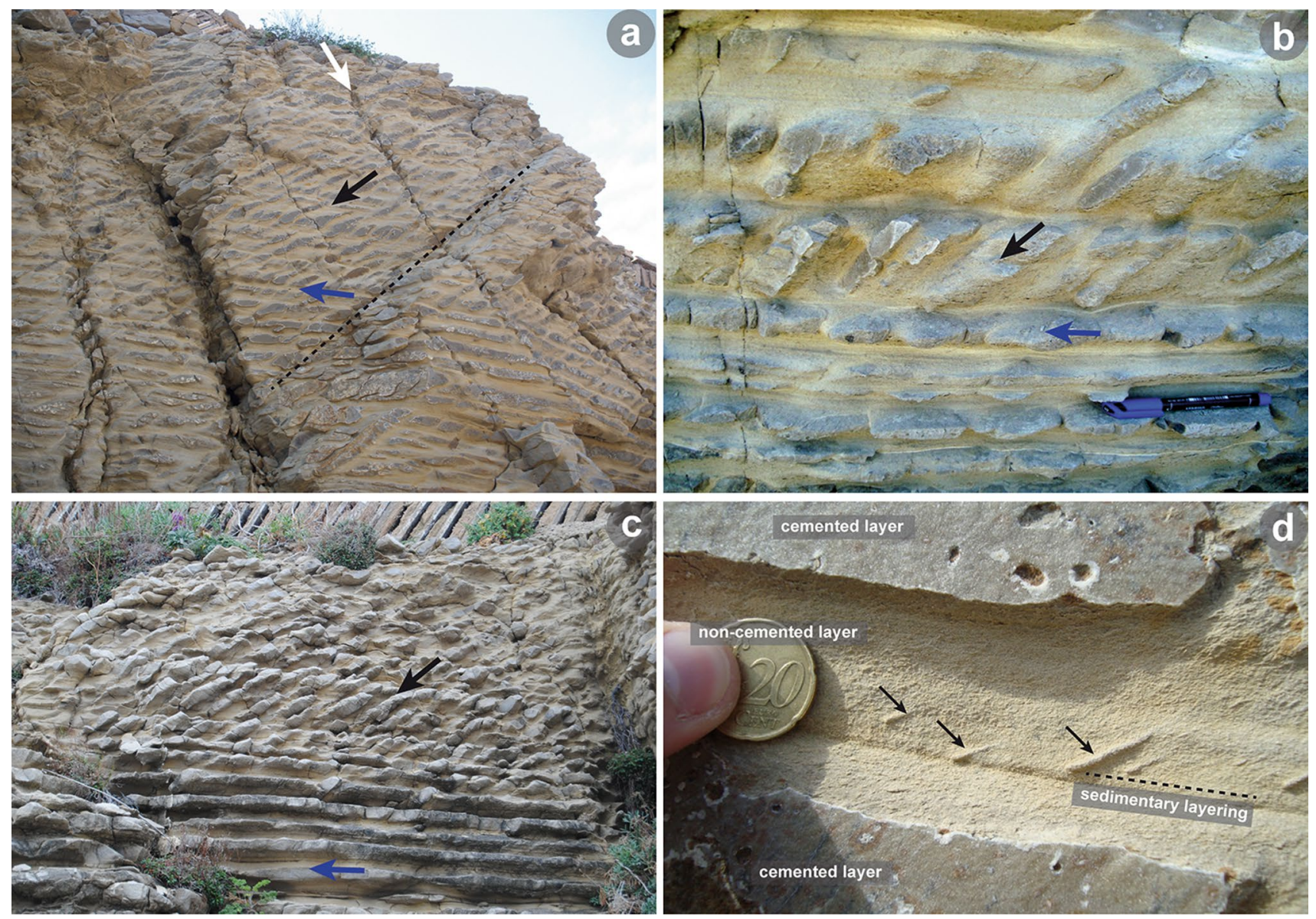

Fig. 2 a Outcrop showing two bed-sets of rhythmic cementation; blue arrow: direction of sedimentary layers; black arrow: direction of oblique bedding; white arrow: later joint; dashed line: joint parallel to oblique cemented beds (height of wall ca. $3 \mathrm{~m}$ ). b Detail of sedimentary layering running horizontally through both sets of cemented limestones (pencil of $18 \mathrm{~cm}$ length for scale); blue arrow: direction of sedimentary layers; black arrow: direction of oblique bedding. c

basin between the Iberian Peninsula created during the late Oligocene to middle Miocene and the Balearic Promontory that forms the northeastern prolongation of the Betic thrust belt (Fontboté et al. 1990; Torres et al. 1993).

The Banyalbufar turbidites are exposed on the western coast of Mallorca (Balearic Islands, Spain) close to the village of Banyalbufar $\left(39^{\circ} 41^{\prime} 29^{\prime \prime} \mathrm{N}, 2^{\circ} 30^{\prime} 50^{\prime \prime} \mathrm{E}\right.$; Fig. 1). They consist of mixed carbonate-siliciclastic silt to sand-grained sediment sourced from the rising Mallorcan orogens and from marine carbonate production. The outcrop studied here has been created during enlargement of a parking lot in 2009 .

Outcrop description was complemented by detailed study of eight samples by means of light-microscope petrography and scanning electron microscopy (SEM). For the latter, the samples were mounted on SEM stubs perpendicular to the stratification, polished, and treated with hydrochloric acid $(0.5 \%)$ for $20 \mathrm{~s}$ for the cemented and
Outcrop close to (a) (height of wall ca. $1.3 \mathrm{~m}$ ). In the lower part of the outcrop, diagenetic bedding follows the sedimentary layers of the turbidite succession; in the upper part, a second, oblique direction of diagenetic bedding occurs. d Detail of sedimentary layering and small-scale cementation in direction of the joints (black arrows). Cemented layers show calcite mineralization on broken surface

$10 \mathrm{~s}$ for the uncemented samples, and afterwards coated with gold. Carbonate content was determined by the calculated difference between the measured TC and TOC values, determined using a LECO Carbon Analyzer. Carbonate is expressed as calcite $\left(\mathrm{CaCO}_{3}=(\mathrm{TC}-\mathrm{TOC}) \times 8.33\right)$.

\section{Results}

The outcrop exposes $3 \mathrm{~m}$ of the stratigraphic succession along a width of $25 \mathrm{~m}$. The succession is preserved as cemented and uncemented beds with an average couplet thickness around $10 \mathrm{~cm}$ (Fig. 2). The outcrop features two sets of cemented beds, one following the sedimentary layers, and a second one at an acute angle to the bedding: Whereas the sedimentary layers dip with $5-10^{\circ}$ (average $\left.8^{\circ}, n=5\right)$ in a northwestern direction $\left(300-350^{\circ}\right.$, average 

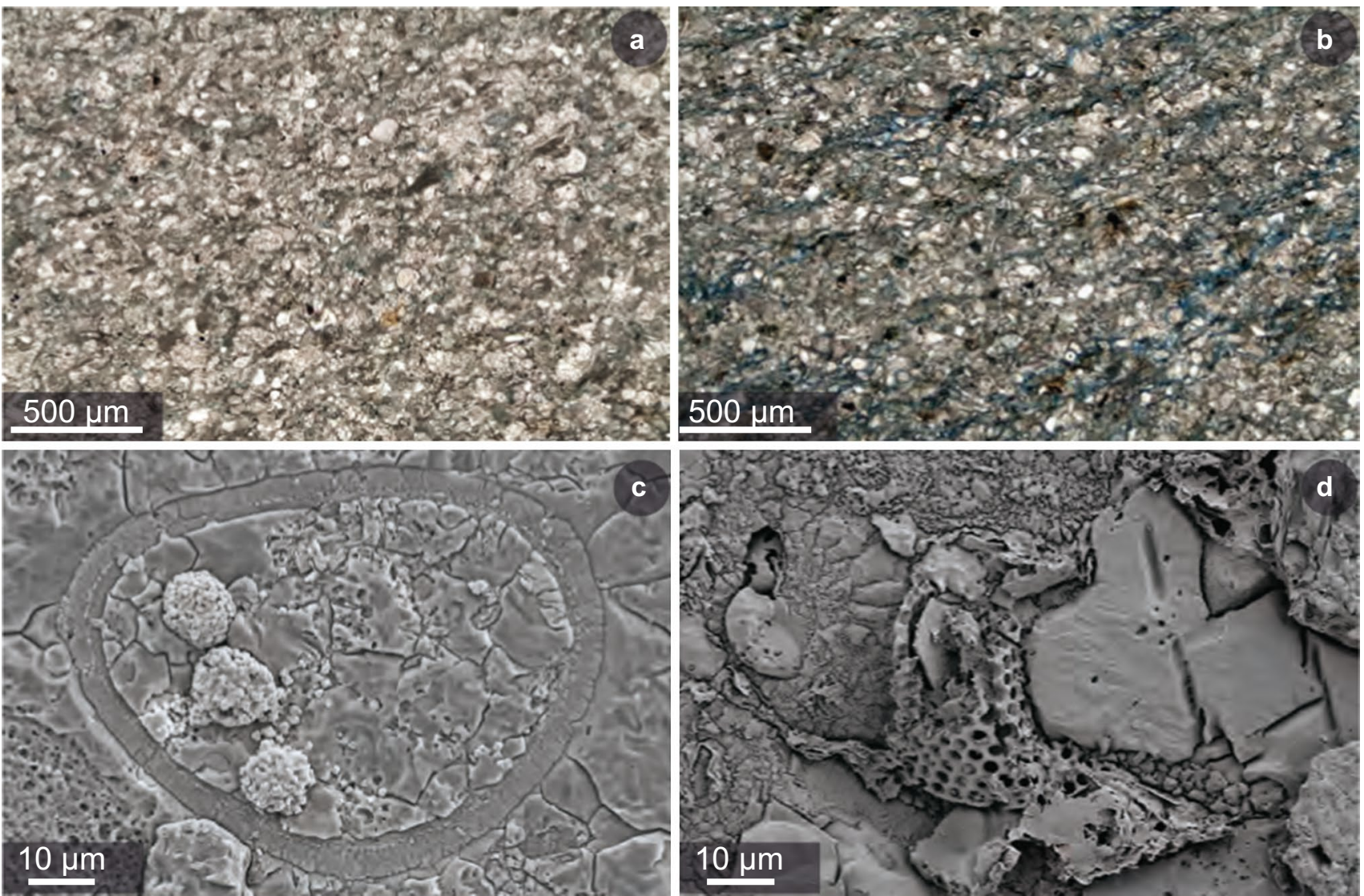

Fig. 3 a Thin-section photograph of cemented bed (packstone) consisting mainly of detrital quartz grains and planktonic foraminifera. $\mathbf{b}$ Thin-section photograph of non-cemented interbed (packstone) also consisting of detrital quartz grains and planktonic foraminifera. Compaction is indicated by texture. Higher porosity is indicated by blue

resin (all samples where impregnated with blue resin before preparation of thin-sections). c SEM micrograph of cemented non-deformed foraminiferal test in a cemented bed. Pyrite framboids are present in the microspar matrix. d SEM micrograph of broken foraminifera test in a non-cemented interbed

$342^{\circ}$ ), the oblique cemented beds dip with $20^{\circ}-35^{\circ}$ (average $\left.27^{\circ}, n=7\right)$ in a southeastern direction $\left(110^{\circ}-150^{\circ}\right.$, average $134^{\circ}$ ).

The succession shows three distinct sets of joints (i.e., tectonically induced disturbance without visible displacement). The most conspicuous joints exposed in the outcrop are oriented parallel to the oblique beds (dotted line in Fig. 2a). Close to these joints, the oblique beds are most continuous and become less prominent with distance from the joints. Another prominent joint direction unrelated to cementation lies almost orthogonal to the latter (white arrow in Fig. 2a).

The sedimentary stratification is clearly visible in the uncemented layers as well as in cemented ones where weathered (Fig. 2b, d). For both sets of beds, the color of the cemented beds is whitish-grey, whereas the uncemented interbeds show a yellow-brownish tone.

Generally, the sediment composition of the succession is rather uniform and consists of well-sorted grains dominated by detrital quartz, planktonic foraminifera, and sponge spicules in a mud matrix for both cemented and uncemented beds (Fig. 3a, b). The couplets are characterized by a slightly coarser-grained base and a finergrained top layer. Carbonate contents of cemented beds average at $81.2 \%$ (range, $80.8-81.4 \% ; n=3$ ), those of the uncemented beds at $60.4 \%$ (range, $56.7-63.2 \%$; $n=4)$.

Petrographically, the cemented beds of both bed-sets (parallel to sedimentary layering and oblique ones) are indistinguishable from each other, and the same holds true for the uncemented beds of both sets. All uncemented beds are classified as packstones, and all cemented ones as packstones to poorly washed grainstones.

Diagenetically, the two bed-sets are also indistinguishable. For both sets, the cemented beds contain low amounts of interparticle and intraparticle sparry cement, whereas the uncemented layers show a higher porosity, compactional features, and dissolution seams (Fig. 3). Where the horizontal and oblique cemented beds merge (Fig. 2b), they do not show a lithological boundary that would imply that 
one set postdates the other; they appear to have undergone cementation synchronously. The absence of significant compaction features in the cemented beds (Fig. 3c) implies that the cementation process was early and prior to significant sedimentary overburden.

\section{Interpretation}

As was pointed out earlier (Jenkyns et al. 1990, p. 57), in the Banyalbufar Formation, "the composite layering [...] appears to be largely due to differential cementation, but this probably reflects original bedding." This interpretation of a bedding-parallel cementation has been confirmed here for one set of cemented beds. The new discovery of the additional oblique bed-set reveals an unequivocally diagenetic feature that is not predefined by sedimentary layering.

As mentioned above, cemented beds in rhythmic calcareous successions in most cases follow the sedimentary layers and are oriented parallel to the sea floor of the time of deposition (Canfield and Raiswell 1991). Combined with sedimentary anisotropies, e.g., in porosity and permeability, diagenetic zones caused by microbially mediated decay of organic matter in many cases forces diagenetic beds to match the orientation of the sedimentary layers. The layer-parallel bedding of the Banyalbufar succession also follows primary anisotropies. At the same time, however, the contemporaneously formed oblique bedding also follows another anisotropy present during early diagenesis. A process that potentially produces such oblique pathways for fluids are syn-sedimentary to early post-sedimentary tectonic movements affecting the consolidated, but not yet cemented, sediment (Fig. 4). The stiffness of the sediment must have allowed small joints to form as opposed to ductile deformation. This is in accordance with the silty to sandy sediment making it more prone to brittle than to ductile deformation, the latter being more typical for muddy sediment. The joints observed in the outcrop studied have not displaced the sediment (Fig. 2d) but have had enough of an effect on the sediment properties to add an additional direction of the physical anisotropy of the sediment. This dual anisotropy led to synchronous cementation, resulting in cemented beds that intersect each other (Fig. 4). The microbially defined diagenetic zones were not tilted, neither were the sediments. They were oriented in their original horizontal position (parallel to the sea floor). The physical properties, however, were changed in the tectonic direction of the joints, thus distorting the diagenetic (microbial) zones according to the now bidirectional anisotropy of physical properties (Fig. 4). Dissolved calcium carbonate (likely derived from dissolution of aragonitic constituents in the uncemented layers, cf. Munnecke and Samtleben 1996) migrated by diffusion into a cementation zone, the

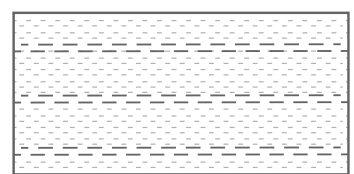

Step 1:

Deposition of turbiditic sediments with a single anisotropy in permeability caused by sedimentary bedding.

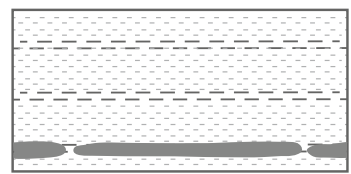

Step 2:

Differential diagenesis (parallel to sedimentary layering; compare lower part in Fig. 2c)

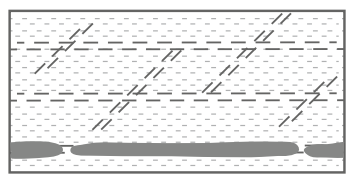

Step 3:

Regional tectonic movement in some areas slightly affects the consolidated but not yet cemented sediment and results in joints leading to a secondary inclined anisotropy.

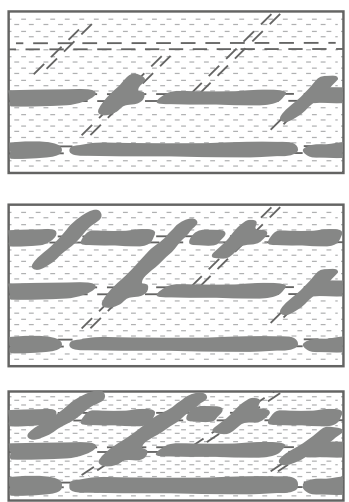

Step 4:

Early marine differential diagenesis preferentially cements zones of higher porosity/permeability regardless of their orientation.

Step 5:

With marine burial diagenesis complete, both directions of anisotropy are thoroughly cemented.

\section{Step 6:}

Continuing sedimentation results in compaction of non-cemented layers.

Fig. 4 Sketch of the process forming the intersecting diagenetic bedding

shape of which is influenced by petrophysical properties (e.g., porosity and permeability), here determined by both sedimentary layers and tectonic joints (Fig. 4).

The scenario requires a syn- to early post-sedimentary tectonic movement, which is in accordance with the tectonic situation in the Burdigalian. During deposition of the Banyalbufar Turbiditic Formation, the area was subject to extensional faulting with local rapid subsidence (Pomar 1979; Ramos-Guerrero et al. 1989; Wadsworth and Adams 1989). This interpretation is supported by the fact that oblique-oriented cemented beds are only observed in the vicinity of tectonic joints and they disappear with distance.

The question about the mechanisms or sediment properties that define the exact position of the cementation zone has not yet been conclusively answered (see discussions in Westphal et al. 2008a, 2008b, 2010). Canfield and Raiswell (1991) and Munnecke and Samtleben (1996) speculated that the zone of anaerobic methane oxidation represents the cementation zone. In modern sediments, this zone is located in shallow burial depths between the sulphate reduction zone and the methanogenesis zone and is characterized by an abrupt increase in carbonate supersaturation. A discussion of this hypothesis, however, is not within the scope of the present paper. 
The Miocene turbidite succession exposed near Banyalbufar illustrates how anisotropies of different origin can influence early diagenesis in a way to produce intersecting sets of cemented beds. Cemented beds thus do not necessarily represent primary sedimentary layers, and, in an extreme case, can even mimic sedimentary layers at an angle to the true sea-floor orientation.

As the long-lasting controversy has demonstrated, bedding without such relation clearly cannot be the basis for astrochronology (see references in Westphal et al. 2010). This example of diagenetic bedding entirely unrelated to sedimentary layers demonstrates that creating a high-resolution, highly precise time-framework needs to be undertaken with great caution. Successions without clear proof of a primary sedimentary signal should not be chosen for GSSPs and other binding stratigraphic data points. Calcareous rhythmic successions are only reliable for sophisticated methods such as astrochronology if a primary, sedimentary origin has been proven independently and unequivocally.

Acknowledgments Guillem Mateu Vicens is gratefully acknowledged for the assistance during field campaigns on the island of Mallorca. We are grateful to Maurice Tucker and two anonymous referees for helpful comments, and to Petra Witte, the workgroup of historical geology and palaeontology at the University of Bremen, for assistance during SEM analyses.

Open Access This article is distributed under the terms of the Creative Commons Attribution License which permits any use, distribution, and reproduction in any medium, provided the original author(s) and the source are credited.

\section{References}

Boulila S, de Rafélis M, Hinnov LA, Gardin S, Galbrun B, Collin P-Y (2010) Orbitally forced climate and sea-level changes in the Paleoceanic Tethyan domain (marl-limestone alternations, Lower Kimmeridgian, SE France). Palaeogeogr Palaeoclim Palaeoecol 292:57-70

Boulila S, de Rafélis M, Hinnov LA, Gardin S, Galbrun B, Collin P-Y (2011) Reply to the comment on "orbitally forced climate and sea-level changes in the Paleoceanic Tethyan domain (marllimestone alternations, Lower Kimmeridgian, SE France)" by S Boulila, M de Rafélis, L A Hinnov, S Gardin, B Galbrun, P-Y Collin [Palaeogeogr. Palaeoclim. Palaeoecol. (2010) 292:57-70]. Palaeogeogr Palaeoclim Palaeoecol 306:252-257

Canfield DE, Raiswell R (1991) Carbonate precipitation and dissolution-its relevance to fossil preservation. In: Allison A, Briggs DEG (eds) Taphonomy-releasing the data locked in the fossil record. Plenum Press, New York, pp 411-453

Einsele G (1982) Limestone-marl cycles (Periodites): diagnosis, significance, causes - a review. In: Einsele G, Seilacher A (eds) Cyclic and event stratification. Springer, Berlin, pp 8-53

Elrick M, Hinnov LA (2007) Millennial-scale paleoclimate cycles recorded in widespread Palaeozoic deeper water rhythmites of North America. Palaeogeogr Palaeoclim Palaeoecol 243:348-372

Fontboté JM, Guimerà J, Roca E, Sàbat F, Santanach P, FernándezOrtigosa F (1990) The Cenozoic geodynamic evolution of the
Valencia through (Western Mediterranean). Rev Soc Geol Espana 3:249-259

Hallam A (1964) Origin of the limestone shale rhythm in the Blue Lias of England: a composite theory. J Geol 72:157-169

Hallam A (1986) Origin of minor limestone-shale cycles: climatically induced or diagenetic? Geology 14:609-612

Jenkyns HC, Sellwood BW, Pomar L (1990) A field excursion to the Island of Mallorca. Geologists' Association Guide, London

Mattioli E, Colombié C, Giraud F, Olivier N, Pittet B (2011) Comment on "Orbitally forced climate and sea-level changes in the Paleoceanic Tethyan domain (marl-limestone alternations, Lower Kimmeridgian, SE France) “ by S Boulila, M de Rafélis, LA Hinnov, S Gardin, B Galbrun, P-Y Collin [Palaeogeogr Palaeoclim Palaeoecol (2010) 292:57-70]. Palaeogeogr Palaeoclim Palaeoecol 306:249-251

Möller NK, Kvingan K (1988) The genesis of nodular limestones in the Ordovician and Silurian of the Oslo Region. Sedimentology 35:405-420

Munnecke A, Samtleben C (1996) The formation of micritic limestones and the development of limestone-marl alternations in the Silurian of Gotland, Sweden. Facies 34:159-176

Munnecke A, Westphal H, Elrick M, Reijmer JJG (2001) The mineralogical composition of precursor sediments of calcareous rhythmites: a new approach. Int J Earth Sci 90:795-812

Pomar L (1979) La evolución tectosedimentaria de las Baleares: análisis crítico. Acta Geol Hisp 14:293-310

Pomar L, Rodríguez-Perea A, Sabat F, Fornós J (1990) Neogene Stratigraphy of Mallorca Island. Paleontologia i Evolució Memòria Especial No. 2; International Union of Geological Sciences, Subcommission on Neogene Stratigraphy, Regional Committee on Mediterranean Neogene Stratigraphy, p 320

Raiswell R (1987) Non-steady state microbiological diagenesis and the origin of concretions and nodular limestones. Geol Soc Spec Pub 36:41-54

Raiswell R (1988) Chemical model for the origin of minor limestone-shale cycles by anaerobic methane oxidation. Geology 16:641-644

Ramos-Guerrero E, Rodríguez-Perea A, Sàbat F, Serra-Kiel J (1989) Cenozoic tectonosedimentary evolution of Mallorca Island. Geodyn Acta 3:53-72

Reinhardt EG, Cavazza W, Patterson RT, Blenkinsop J (2000) Differential diagenesis of sedimentary components and the implication for strontium isotope analysis of carbonate rocks. Chem Geol $164: 331-343$

Ricken W (1986) Diagenetic bedding - a model for marl-limestone alternations. Lecture Notes in Earth Sciences 6. Springer, Heidelberg

Rodríguez-Perea A (1986-1987) Megaturbiditas calcáreas en el Mioceno de Mallorca. Formación turbidítica de Banyalbufar. Acta Geol Hisp 21-22:283-292

Seibold E (1952) Chemische Untersuchungen zu Bankung im unteren Malm Schwabens. N Jb Geol Paläont Abh 95:337-370

Sujkowski ZL (1958) Diagenesis. AAPG Bull 42:2692-2717

Torres J, Bois C, Burrus J (1993) Initiation and evolution of the Valencia Trough (Western Mediterranean): constraints from deep seismic profiling and subsidence analysis. Tectonophysics 228:57-80

Wadsworth WJ, Adams AE (1989) Miocene volcanic rocks from Mallorca. Proc Geol Assoc 100:107-112

Walter LM, Burton EA (1990) Dissolution of recent platform carbonate sediments in marine pore fluids. Am J Sci 290:601-643

Walter LM, Bischof SA, Patterson WP, Lyons TW (1993) Dissolution and recrystalization in modern shelf carbonates: evidence from pore water and solid phase chemistry. Phil Trans R Soc Lond A 344:27-36

Westphal H, Head MJ, Munnecke A (2000) Differential diagenesis of rhythmic limestone alternations supported by palynological evidence. J Sediment Res 70:715-725 
Westphal H, Munnecke A, Brandano M (2008a) Effects of diagenesis on the astrochronological approach of defining stratigraphic boundaries in calcareous rhythmites: the Tortonian GSSP. Lethaia 41:461-476

Westphal H, Munnecke A, Böhm F, Bornholdt S (2008b) Limestone-marl alternations in epeiric sea settings-witnesses of environmental changes, or of rhythmic diagenesis? Geol Assoc Can Spec Pap 48:389-406

Westphal H, Hilgen F, Munnecke A (2010) An assessment of the suitability of individual rhythmic carbonate successions for astrochronological application. Earth Sci Rev 99:19-30 